\title{
Implementasi Standar Akuntansi Keuangan Tax Amnesty (Psak 70): Cermin Kepatuhan Pajak
}

Nurmala Ahmar

Sekolah Tinggi Ilmu Ekonomi (STIE) Perbanas, Surabaya, Indonesia

\section{INFO ARTIKEL \\ JEL Classification : H21, G32, M41}

\section{Keywords :}

tax amnesty, kepatuhan, PSAK 70, financial institution

\begin{abstract}
The Financial Services Authority (OJK) stipulates that tax amnesty ends on March 31, 2017. The institution claims the program is able to improve banking liquidity. This study aims to investigate the effectiveness of the implementation of the tax amnesty program which is regulated by the presentation of the report based on PSAK 70. The sample is 93 companies from 5 financial institutions. These financial institutions are banks, insurance, financial institutions, securities, and other investment companies. The observation period was carried out during 2016. The results of the study found that more banking financial institutions did not participate in the tax amnesty program than those who participated. The same thing was found in financial institutions. Securities companies and other financial institutions were found to have greater participation, while insurance companies were found to have balanced participation. The results of these studies can be the basis of policy regarding recurring policies related to tax amnesty in Indonesia because participation from the banking sector in terms of implementation of PSAK 70 is still dominated by nonparticipation status.
\end{abstract}

\begin{abstract}
ABSTRAK
Otoritas Jasa Keuangan menetapkan bahwa pengampunan pajak yang berakhir pada 31 Maret 2017. Institusi tersebut mengklaim program tersebut mampu memperbaiki likuiditas perbankan. Penelitian ini bertujuan menginvestigasi efektifitas implementasi program pengampunan pajak yang diatur penyajian laporannya perdasarkan PSAK 70. Sampel adalah 93 perusahaan dari 5 lembaga keuangan. Lembaga keuangan tersebut adalah bank, asuransi, lembaga pembiayaan, sekuritas, dan perusahaan invstasi lainnya. Masa observasi dilakukan selama tahun 2016. Hasil penelitian menemukan bahwa lembaga keuangan perbankan lebih banyak yang tidak berpartisipasi pada program tax amnesty dibandingkan yang berpartisipasi. Hal yang sama ditemukan pada lembaga pembiayaan. Perusahaan sekuritas dan lembaga keuangan lain ditemukan memiliki partisipasi lebih besar, sedangkan perusahaan asuransi ditemukan memiliki partisipasi yang berimbang. Hasil penelitian tersebut dapat menjadi dasar kebijakan tentang kebijakan berulang terkait tax amnesty di Indonesia karena partisipasi dari sector perbankan ditinjau dari implementasi PSAK 70 masih didominasi status tidak berpartisipasi dan dengan kata lain kepatuhan pajak yang diukur daripartisipasi tax amnesty masih belum optimum
\end{abstract}




\section{Pendahuluan}

Program amnesti pajak diberlakukan sejak disahkan hingga 31 Maret 2017. Pelkasanaan program terbagi ke dalam tiga periode. Periode pertama dimulai saat tanggal diundangkan sampai dengan 30 September. Periode kedua dimulai 1 Oktober 2016 sampai dengan 31 Desember 2016. Periode ketiga berlaku mulai 1 Januari sampai dengan 31 Maret 2017. Perusahaan yang melakukan tax amnesty atau berpartisipasi dalam tax amnesty, khususnya perusahaan publik, akan melaporkan pelaksanaan dan pelaporan tax amnesty pada akhir tahun buku Desember 2017. Tanggapan masyarakat untuk program pengampunan pajak pada periode pertama sangat positif. Partisipan program tersebut bukan hanya masyarakat yang sudah tercatat sebagai Wajib Pajak (WP), tetapi juga para WP baru. Pada periode pertama, tercatat sejumlah Rp3.500 triliun harta yang dilaporkan dari harta di dalam negeri dan luar negeri. Target pelaporan harta warga negara Indonesia dari luar negeri untuk dibawa ke dalam negeri adalah Rp1.000 triliun dan pelaporan aset sebesar Rp4.000 triliun. Sementara itu, dana yang ditebus dalam program tax amnesty hingga 30 September 2016 mencapai sekitar Rp92,99 triliun dari target Rp165 triliun. Periode kedua mencatat realisasi penerimaan uang tebusan amnesti pajak sebesar Rp103,31 triliun atau baru $62,6 \%$ dari target Rp165 triliun. Dengan capaian periode pertama sebesar Rp92,99 triliun, realisasi penerimaan uang tebusan pada periode kedua adalah sebesar Rp10,32 triliun atau sekitar 9,98\% dari total raupan uang tebusan. Dengan kata lain capaian ini masih belum dapat dikatakan sukses. Program tax amnesty pada periode ketiga, realisasi uang tebusan berdasarkan penerimaan surat setoran pajak samapai dengan 2 Januari 2017 mencapai Rp107 triliun atau sekitar $64,8 \%$ dari target Rp165 triliun.

Program pengampunan pajak alias tax amnesty sudah berakhir. Capaian akhir selama 3 periode mencapai $81,8 \%$. Jumlah Hasilnya uang tebusan terkumpul dari tiga periode penyelenggaraan tax amnesty harta deklarasi sekitar Rp4.865 triliun dan uang tebusan sebesar Rp135 triliun merupakan hasil tertinggi di dunia diantara negaranegara yang melakukan program tax amnesty. Turki dan Chili menduduki peringkat kedua dan ketiga. Apakah kondisi ini menecerminkan kepatuhan wajib pajak yang tinggi di Indonesia? Kepatuhan menurut Direktorat Jenderal Pajak merupakan kepatuhan membayar dan kepatuhan melapor. Menindaklanjuti program tax amnesty, Ikatan Akuntan Indonesia menerbitkan standar akuntansi penganpunan Pajak sebagai pedoman penilaian, pengukuran, pencatatan, pelaporan/penyajian dan pengungkapan atas kegiatan atau transaksi tax amnesty. Perusahaan yang berpartisipasi tentu akan melaporkan transaksi tersebut dalam laporan keuangannya sebagai indikator pelaksanaan tax amnesty pada entitasnya. Penelitian ini menganalisis kepatuhan mengikuti program tax amnesty dengan indikator implementasi PSAK 70. Penelitian juga menganalisis perbedaan kinerja perusahaan yang melakukan dan tidak melakukan tax amnesty.

\section{Telaah Teori dan Pengembangan Hipotesis}

Indonesia merupakan salah satu negara di dunia yang pernah melaksanakan pengampunan pajak. Sejak tahun 1964 sampai dengan tahun 2008, tercatat Indonesia telah melakukan tiga kali pengampunan pajak, yaitu pada tahun 1964, tahun 1984, dan tahun 2008. Sejarah tax amnesty di Indonesia dimulai pada tahun 1964 atau 20 tahun setelah Kemerdekaan Indonesia. Kebijakan Pemerintah Indonesia yang terkait pengampunan pajak (tax amnesty) ini bertujuan untuk mengembalikan dana revolusi, melalui perangkat Keputusan Presiden Republik Indonesia (Keppres). Sejarah tax amnesty tahun 1964 ini berakhir pada 17 Agustus 1965.

Amnesti pajak bisa menjadi alat kebijakan pajak. Amnesti juga dapat digunakan secara sistematis sebagai mekanisme diskriminatif untuk meningkatkan efisiensi atau bahkan pemerataan sistem pajak (Marchese, 2014). Hal ini dapat dilakukan jika pemerintah 
memiliki komitmen dan dapat dipercaya untuk menegakkan hukum pajak. Jika kredibilitas pemerintah kurang, amnesti mungkin dapat mengurangi pendapatan pajak di masa depan. Kondisi ini dapat terjadi karena, secara psikologis, amnesty pajak merupakan kesepakatan antara pemerintah dengan wajib pajak untuk melakukan pelanggaran secara legal. Kebijakan ini dapat muncul kembali untuk kepentingankepentingan tertentu, misalnya untuk kepentingan politik. Pada akhirnya tax amnesty hanya merupakan alat kebijakan (Bose dan Jetter, 2012). Namun, melalui kebijakan tax amnesty, pemerintah dapat melakukan deteksi terhadap wajib pajak nakal, meningkatkan pendapatan dan kesejahteraan masyarakat dari sector pajak.

Amnesty pajak dapat memicu kepatuhan wajib pajak (Alfiyah dan Latifah, 2016; Yasa dan Mandala, 2016). Temuan berbeda oleh Suyanto dan Putri (2017) membuktikan bahwa persepsi wajib pajak tentang kebijakan tax amnesty tidak memiliki pengaruh yang positif terhadap kepatuhan perpajakan, dan motivasi wajib pajak memiliki pengaruh positif terhadap kepatuhan perpajakan.

Yasa dan Mandala (2016) mengatakan bahwa penerapan tax amnesty berimplikasi terhadap beberapa hal diantaranya, peningkatan jumlah wajib pajak, peningkatan penerimaan pendapatan negara, dan membantu mempercepat pembangunan infrastruktur untuk mempermudah masyarakat melakukan aktivitas ekonomi, sehingga berharap kesejahteraan meningkat. Ragimun (2013) mengatakan bahwa penerapan tax amnesty di Indonesia masih merupakan wacana yang pro dan kontra pada tahun 2012. Pada dasarnya penerapan kebijakan ini diharapkan dapat meningkatkan jumlah wajib pajak, subyek dan obyek pajak sekaligus meningkatkan penerimaan negara dari dana-dana yang di "parkir" di luar negeri.

Kepatuhan dan penghindaran pajak adalah keputusan yang kompleks yang dimotivasi oleh berbagai faktor. Adanya ancaman hukuman, pemeriksaan bagi yang tidak mengikuti program kebijakan pajak (tax amnesty) menyebabkan tingkat kepatuhan meningkat. Cummings, et al (2009) dan Nar (2015) menghubungkannya dengan prospect theory dan rank-dependent expected utility. Teori tersebut menyatakan bahwa orang membuat keputusan berdasarkan nilai kerugian dan keuntungan potensial daripada hasil akhir, dan orang mengevaluasi kerugian dan keuntungan ini dengan menggunakan cara penemuan (heuristic) tertentu. Wajib pajak akan menghitung untuk dan rugi bagi mereka jika mengikuti tax amnesty. Mereka akan berperilaku seolah-olah mereka akan menghitung nilai (utilitas), berdasarkan hasil potensial dan probabilitas masing-masing, dan kemudian memilih alternatif yang memiliki utilitas lebih tinggi.

Di lain pihak ketidakikutsertaan dalam program tax amnesty juga akan menjadi pemicu sanksi norma social. Cyan, et al (2016), Sari dan Fidiana (2017) bahkan membuktikan bahwa tingkat pendidikan mempengaruhi kepatuhan wajib pajak. Tingkat pemahaman terkait erat dengan tingkat pengetahuan. Akuntan sebagai warga Negara yang berpendidikan seharusnya mendukung kebijakan pemerintah tersebut. Setyaningsih dan Oktifitasari (2012) mencoba melakukan eksplorasi pendapat wajib pajak, temuannya adalah pajak masih merupakan sebentuk gangguan dan menimbulkan ketakutan di masyarakat. Wajib pajak melakukan program pengampunan pajak bekerjasama dengan pihak luar (konsultan pajak). Akuntan public memiliki peran penting dalam memberikan konsultasi.

Hasil positif yang diharapkan dapat diberikan jika hanya amnesti pajak yang dirancang dengan baik, praktik tersebut di atas tidak diterapkan secara berkala, dan kerugian dan pendapatan yang akan terjadi dalam jangka pendek dan panjang disajikan dengan cukup jelas. Lebih jauh lagi, penting untuk menerapkan diskriminasi positif untuk memberi penghargaan kepada pembayar pajak yang jujur pada saat ini. Membuat 
potongan pajak untuk pembayar pajak, yang membayar pajak mereka secara teratur, dapat dianggap sebagai "keadilan yang berasal dari ketidakadilan" secara parsial meskipun ada sesuatu yang menarik pada temuan Tofan (2017), dimana wajib pajak yang disiplin menganggap dirinmya tidak beruntung.

Pada sudut pandang yang berbeda, Bose dan Jetter (2012) berpendapat bahwa kondisi ekonomi yang baik mungkin juga memberi motivasi untuk memberikan amnesti. Jika ekonomi berkembang dengan cepat berkat kebijakan liberalisasi dan pembukaan perdagangan internasional, mungkin saja perusahaan dapat memperoleh keuntungan lebih banyak di lingkungan baru jika mereka legal dan memiliki catatan pajak yang bersih, karena ini membuka jalan untuk mengakses pasar kredit atau untuk pencatatan di bursa efek dan sebagainya. Bagi perusahaan yang telah beroperasi selama beberapa waktu dalam ekonomi tersembunyi, namun beralih ke legalitas bisa menyiratkan biaya yang besar dalam hal sanksi atas penghindaran masa lalu, dan amnesti dapat mengurangi roda perubahan. Hasil amnesti dalam kasus ini harus dievaluasi tidak hanya dengan mengacu pada dampak pada pendapatan pajak, namun juga dampaknya terhadap PDB yang harus terjadi berkat peningkatan produktivitas di perusahaan yang dapat beralih ke legalitas.

Indonesia telah menerapkan amnesti pajak pada tahun 1964, 1984 dan 2016. Amnesti pajak pada tahun 1964 dan 1984 dianggap tidak berhasil karena kondisi politik pada saat itu dan ketidaktahuan pemerintah terhadap program tersebut. Ini sangat berbeda dengan Afrika Selatan, India, dan Italia yang berhasil menerapkan program amnesti pajak (Huda dan Hernoko, 2017). Amnesti pajak tahun 2016 harus berhasil, dan untuk melakukannya, pemerintah tidak hanya menghapuskan hak koleksi terhadap pembayar pajak tetapi juga meningkatkan kesadaran para pembayar pajak untuk meningkatkan pendapatan anggaran nasional, meningkatkan data pembayar pajak, meningkatkan stok devisa melalui mata uang asing masuk, investasi terbuka, menciptakan panggilan baru dan mendorong reformasi birokrasi pajak. Pemerintah juga harus melakukan tindakan nyata untuk meningkatkan penerimaan pajak dengan melakukan sensus pajak nasional dan memperbaiki pelaksanaan program Indonesian National Single Windows (INSW).

Pengampunan pajak secara berulang merupakan kajian yang menarik. Shevlin, et al (2017) menunjukkan bahwa program pengampunan pajak yang berulang kali memiliki implikasi yang semakin negatif terhadap koleksi pajak perusahaan. Wang dan Hsieh (2015) memberikan pertimbangan lain, dimana orang-orang yang berpartisipasi dalam program amnesti pajak mungkin tidak secara jujur melaporkan keseluruhan jumlah pajak yang terhindar, hal itu menyebabkan penghindaran pajak sekunder. Tax amnesty dapat dimaknain sebagai ketidakpastian hukuman penghindaran pajak. Partisipasi dalam program amnesti pajak memberikan tingkat utilitas yang lebih tinggi untuk seorang penghindar pajak. Hasil ini mencerminkan pengamatan bahwa banyak penjahat pajak bersedia membayar pajak walaupun tingkat penalti yang diharapkan dan kemungkinan tertangkap menghindari pajak sangat rendah. Juga, karena penghindaran pajak sekunder disertai amnesti pajak, Dengan demikian, ini menunjukkan bahwa selama periode penilaian awal rencana amnesti pajak, penerimaan pajak meningkat secara drastis, dan kemudian ketika masa penilaian berakhir, pendapatan pajak secara stabil menurun dan pada akhirnya menyatu dengan besaran tetap.

Berdasarkan data dengan kurun waktu panjang (1981-2011) Bayer, et al (2015) menemukan kecenderungan perilaku wajib pajak yang mengharapkan akan terjadi kembali tax amnesty. Riset ini juga membuktikan bahwa motivasi kebijakan tax amnesty oleh pemerintah didominasi oleh kepentingan target pemenuhan pendapatan negara dalam jangka pendek. Wajib pajak seolah meyakini bahwa kebutuhan 
pemenuhan anggaran pendapatan pemerintah dari pajak di masa depan berdampak pada kebijakan tax amnesty ulang di masa mendatang.

Program amnesti pajak di Bangladesh telah menciptakan efek yang merugikan pada ekonomi Negara (Waris dan Latif, 2014) Pembayar pajak yang mengikuti program amnesti pajak dilindungi oleh pemerintah meskipun mereka hanya melaporkan $1 \%$ dari uang hitam mereka karena mereka mendapat lisensi untuk memutihkan sejumlah uang hitam. Ada beberapa celah dalam cakupan pelanggaran, cakupan pelanggaran predikat dan jenis properti yang tercakup dalam tindak pidana pencucian uang. Ada juga tidak adanya sanksi keuangan yang tersedia untuk memberi sanksi hukum kepada orang-orang yang berwenang secara efektif. Pelanggaran pencucian uang saat ini berasal dari peraturan yang dikeluarkan pada tahun 2008 oleh pemerintah sementara (2006-2008). Tindakan saat ini berisi definisi terperinci tentang pencucian uang dan properti dan daftar pelanggaran predikat dan sanksi atas pelanggaran tersebut. Namun, ada beberapa celah dalam elemen fisik dari pelanggaran tersebut, dan rentang pelanggaran predikatnya tetap terlalu sempit. Amnesti pajak di Italia secara informal dikenal sebagai 'perisai pajak' (scudo fiscale) berdasarkan perlindungan yang diberikan kepada pembayar pajak yang secara sukarela mengungkapkan atau memulangkan aset asing yang tidak diumumkan, telah menghasilkan evolusi yang menarik dalam penilaian kepercayaan untuk tujuan pajak Italia (Panico, 2010).

Bagaimana pasar bereaksi atas kebijakan amnesty pajak? Dampak peristiwa amnesty pajak dibuktikan dengan menguji reaksi pasar di Indonesia dilakukan oleh Asmorojati, dkk (2017) dan Wibowo dan Darmanto (2017). Abnormal return dan aktivitas volume perdagangan saham sebelum dan sesudah peristiwa berlakunya Undang-Undang Tax amnesty paa perusahaan LQ-45 selama periode periode Februari 2016-Juli 2016 mengalami penurunan. dan rata-rata volume aktivitas perdagangan (TVA) yang mengindikasikan bahwa Investor pasar modal Indonesia tidak bereaksi positif terhadap kejadian amnesti pajak (Asmorojati, dkk, 2017). Hal berbeda ditemukan oleh Wibowo dan Darmanto (2017, dimana terjadi peningkatan rata-rata abnormal kembali antara tanggal acara dan pasca acara pelaksanaan amnesti pajak dan pra event dan pasca acara pelaksanaan amnesti pajak, namun di sisi lain ada penurunan aktivitas rata-rata volume perdagangan (TVA), hal tersebut menunjukkan bahwa kenaikan abnormal return hanya pseudo, karena tidak disertai dengan kenaikan volume aktivitas perdagangan, sehingga dapat disimpulkan bahwa tidak ada reaksi investor pasar modal Indonesia terhadap terjadinya amnesti pajak.

Ahmar (2018) membuktikan bahwa akuntan public memiliki peran penting dalam keberhasilan tax amnesty di Indonesia. Riset dilakukan pada kurun waktu pemberlakuan tax amnesty sampai dengan masa taxamnesty selesai tahun 2016. Pada industry jasa keuangan dan perbankan, kantor akuntan publik (KAP) besar dan terafiliasi dengan big 4 tidak banyak merekomendasi tax amnesty kepada klien yang diauditnya pada sector jasa keuangan dan perbankan. Hal tersebut terlihat dari jumlah emiten dari sector yang diaudit KAP Big 4 Indonesia tidak mengungkapkan implementasi PSAK 70 sebagai bagian pengungkapan dalam laporan keuangannya. Sebaliknya banyak emiten pada sector jasa keuangan yang diaudit oleh KAP Non-Big 4 banyak mengungkap PSAK 70 dan implementasinya. Pertanyaan besar muncul, bagaimana peta implementasi PSAK 70 sebagai refleksi kepatuhan pajak terkait tax amnesty. Temuan riset tersebut sangat penting untuk pertimbangan pengulangan kebijakan ekonomi yang sejenis pada masa mendatang. Berdasarkan dukungan empiris diatas penelitian ini menduga ada perbedaan partsipasi tax amnesty pada sektor industri lembaga keuangan. Ada perbedaan kinerja perusahaan sampel yang berpartisiapsi dan tidak berpartispasi pada program tax amnesty. Hasil penelitian diharapkan dapat 
memberikan kontribusi untuk pengambilan kebijakan ulang, jika dimungkinkan, program tax amnesty di Indonesia.

\section{Metode Penelitian}

Penelitian ini adalah penelitian kuantitatif dengan tujuan menganalisis kepatuhan wajiab pajak dalam berpartisipasi pada program tax amnesty. Kepatuhan berpartisipasi diukur dengan penungkapan PSAK 70 pada laporan keuangan sampel. Jika perusahaa $\mathrm{n}$ mengimplementasi PSAK 70 tentang pengampunan pajak maka sampel melakukan tax amnesty. Sampel adalah institusi keuangan yang terdaftar di Bursa Efek Indonesia. Pengamatan dilakukan pada laporan keuangan perusahaan setelah program tax amnesty berakhir yang mebawa konsekuensi melaporkan bilama mereka berpartisipasi atau mengimplementasi PSAK 70. Meskipun PSAK 70 bukan merupakan indikator utama kepatuhan, namun partsipasi dalam program tax amnesty yang tercermin dari implementasi PSAK 70 diharapkan dapat menjadi indikator apakah program tax amnesty cukup berhasil atau tidak. Pengujian dilakukan dengan crostabulation. kelompok perusahaan yang mengungkap dan tidak mengungkap PSAK 70. Analisis dikembangakan dengan menguji pengaruh tax amnesty terhadap kinerja. Pengujian dilakukan uji beda 2 sampel tidak berpasangan antara perusahaan yang melakukan dan tidak melakukan tax amnesty. Pengujian juga dilakukan antar sektor pada institusi keuangan khususnya yang melakukan tax amnesty.

\section{Hasil Penelitian dan Pembahasan}

Lembaga keuangan merupakan badan usaha yang asetnya berbentuk aset keuangan.lembaga ini sangat diperlukan dan berperan sebagai mediator antara pemilik dana dan pihak yang membutuhkan dana. Kementerian keuangan melalui Dirjen Pajak mengatur juga pembayaran pajak atas aset keuangan. Aset keuangan dan investasi dilaporkan pada bagian Penghasilan, Harta dan Kewajiban apabila ada. Pengenaan pajak atas aset keuangan didasarkan pada aturan yang berlaku. Namun, pengetahuan masyarakat dan pelaku bisnis terkait aset keuangan dan pajak yang menyertainya belum sepenuhnya dipahami dengan baik. Disamping bertujuan untuk menarik dana para wajib pajak yang diduga tersimpan di negara-negara yang bebas pajak, salah satu tujuan lain pengampunan pajak adalah memberi kesempatan kepada masyarakat untuk meningkatkan literasi pajak. Adanya pengampunan pajak diharapkan pelaku bisnis dan masyarakat menjadi lebih patuh karena pengetahuan dan pemahaman mereka tentang pajak semakin baik.

Penelitian ini menguji pengaruh peristiwa pengampunan pajak terhadap kinerja perusahaan pada lembaga keuangan baik perbankan maupun non perbankan. Pengujian dilakukan dengan menguji perbedaan kinerja keuangan lembaga keuangan yang berpartisipasi dan tidak berpartisipasi dalam program tax amnesty. Riset juga perbedaan kinerja keuangan perusahaan yang melakukan dan tidak melakukan tax amnesty. Riset dilakukan selama periode pemberlakuan tax amnesty danIdentifikasi berperan dan tidak berperan dalam program tax amnesty.

Jumlah sampel yang menyajikan pengungkapan terkait pengampunan pajak tidak lebih dominan karena proporsi sampel yang tidak mengungkapkan lebih banyak. Pada jasa perbankan dan lembaga keuangan terbukti lebih banyak yang tidak melakukan tax amnesty. Pada kelompok jasa sekuritas, asuransi, dan jasa investasi perusahaan sekurutas, asuransi, dan jasa investasi yang menyajikan pengungkapan pengampunan. Analisis dilakukan lebih lanjut dengan dengan melakukan uji beda return dan rasio keuangan. Dari tiga rasio keuangan yang diuji tingkat risiko (debt equity ratio) berbeda pada sampel yang melakukan tax amnesty dan tidak melakukan tax amnesty. 
Tabel 1: Implementasi PSAK 70 Tax amnesty pada Lembaga Keuangan

\begin{tabular}{lrrrrrrr}
\hline \multirow{1}{*}{ Sektor } & \multicolumn{2}{c}{$\begin{array}{c}\text { Non-PSAK 70 } \\
\text { Disclosure }\end{array}$} & \multicolumn{2}{c}{$\begin{array}{c}\text { PSAK 70 } \\
\text { Disclosure }\end{array}$} & \multicolumn{2}{c}{ Total } \\
& Jumlah & $\mathbf{\%}$ & Jumlah & $\mathbf{\%}$ & Jumlah & $\mathbf{\%}$ \\
\hline Perbankan & 26 & 28 & 18 & 19,4 & 44 & 47,4 \\
Lembaga Keuangan & 8 & 8,6 & 7 & 7,5 & 15 & 16,1 \\
Sekuritas & 5 & 5,4 & 6 & 6,5 & 11 & 11,8 \\
Asuransi & 7 & 7,5 & 7 & 7,5 & 14 & 15,1 \\
Jasa Investasi & 4 & 4,3 & 5 & 5,4 & 9 & 9,7 \\
Jumlah & $\mathbf{5 0}$ & $\mathbf{5 3 , 8}$ & $\mathbf{4 3}$ & $\mathbf{4 6 , 3}$ & $\mathbf{9 3}$ & $\mathbf{1 0 0}$ \\
\hline
\end{tabular}

Implementasi PSAK 70 bukan merupakan indikator dalam mengukur kepatuhan wajib pajak. Direktorat Jenderal Pajak mendefiniskkan kepatuhan dalam 2 hal, pertama kepatuhan membayar dan kedua, kepatuhan melapor. Implementasi PSAK 70 merupakan bagian penting dalam hal kepatuhan melaporkan. Bilamana emiten melakukan dan atau berpartisipasi dalam program tax amnesty maka ada kewajiban untuk mencatat atau melaporakan. Standar akuntansi keuangan berisi mengatur tata cara penilaian dan pengukuran, pencatatan, penyajian/pelaporan dan pengungkapan. Berdasarkan hasil observasi tersebut tampak bahwa institusi keuangan yang belumberpartsipasi dalam program tax amnesty lebih banyak dibandingkan yang berpartisipasi, sementara semua perusahaan memeiliki kesempatan untuk melakukan pengampunan pajak. Ada 2 kemungkinan mengapa hal ini terjadi, perusahaan yang belum berpartisipasi masih belum siap dan menghindari pengampunan pajak dengan pertimbangan-pertimbangan tertentu. Kedua, perusahaan yang tidak mengungkapkan kegiatan pengampunan pajak adalah perusahaan-perusahaan yang memang telah patuh. Patuk membayar dan patuh melapor, karena institusi keungan adalah institusi yang diregulasi dengan sangat ketat.

Mengkaji lebih mendalam penelitian ini melakukan pengujian pengaruh mlementasi tersebut terhadap kinerja keuangan dengan acara melakukan uji beda kinerja keuangan pada kelompok perusahaan yang melakukan tax amnesty dan perusahaan yang tidak melakukan tax amnesty.berikut adalah rangkuman hasilnya. Perbedaan secara hanya terjadi pada tingkat risiko.

Tabel 2: Hasil Uji Beda Kinerja Keuangan Berdasarkan Implementasi PSAK 70 Tax amnesty

\begin{tabular}{|l|r|r|r|r|r|}
\hline \multicolumn{1}{|c|}{ Keterangan } & \multicolumn{1}{c|}{ RET } & \multicolumn{1}{c|}{ CR } & \multicolumn{1}{c|}{ EPS } & \multicolumn{1}{c|}{ DER } & \multicolumn{1}{c|}{ ROA } \\
\hline Mann-Whitney U & 1069,500 & 1050,000 & 956,000 & 786,500 & 1020,000 \\
Wilcoxon W & 2015,500 & 2325,000 & 1902,000 & 1732,500 & 2295,000 \\
& $-0,042$ & $-1,078$ & $-0,917$ & $-2,223$ & $-0,424$ \\
Z & 0,966 & 0,281 & 0,359 & 0,026 & 0,672 \\
\hline
\end{tabular}

a. Grouping Variable: status 
Secara umum, nilai return perusahaan jasa investasi memiliki peringkat tertinggi diikuti perusahaan sekuritas, dan lembaga keuangan. Perusahaan asuransi memiliki peringkat terendah. Kondisi ini menunjukkan bahwa perusahaan yang beperan dalam program tax amnesty kurang diminati investor. Bursa Efek Indonesia mencatat bahwa kinerja saham sub sektor asuransi kurang atraktif, tidak likuid dan jarang ditransaksikan oleh investor. Seharusnya potensi pertumbuhan industri asuransi di Indonesia masih terbuka luas karena belum banyak masyarakat yang memproteksi dirinya dengan asuransi.

Hal menarik tampak pada return on asset. Rasio ini merupakan indikator untuk menilai kemampuan perusahaan menghasilkan keuntungan. Meskipun perusahaan asuransi tidak banyak diminati investor dan jarang ditransaksikan, namun kemampuan mereka menghasilkan laba menduduki peringkat tertinggi. rasio tingkat pengembalian aset banyak digunakan oleh investor, direksi, kreditur, calon investor, analis, dan pihak lainnya ketika menilai kinerja perusahaan. efisiensi penggunaan asetperusahaan tercermin dari nilai roa karena angka tersebut dapat menggambarkan seberapa efektif kemampuan perusahaan mengubah dana yang diinvestasikan menjadi laba bersih.

Konsisten dengan hasil RoA laba per saham tertinggi juga dimiliki oleh subsektor asuransi. Dan terendah pada perusahaan sekuritas. Bursa mencatat dalam periode perdagangan saham perusahaan sekuritas dilelang untuk menarik minat investor. Hal lain dimungkinkan karena perusahaan belum banyak mendapatkan literasi tentang perusahaan sekuritas. Emiten ini bergerak di bidang transaksi jual beli efek atau surat berharga yangdapat diperjualbelikan.

Temuan menarik adalah kinerja keuangan perusahaan yang melakukan tax amnesty dalam hal risiko perusahaan. Perusahaan perbankan memilki risiko tertinggi, dengan RoA terendah, return juga masuk peringkat yang rendah. Perusahaan sekuritas memiliki peringkat risiko terendah dibandingkan sub sektor lembaga keuangan yang lain. Return perusahaan sekuritas relatif tinggi dibandingkan lembaga keuangan lain, namun minat investor rendah, terbukti return berada pada peringkat terendah. Pada masa pengampunan pajak kondisi ini dapat dmanfaatkan oleh investor untuk mengambil keputusan investasi.

Tabel 3: Rank rasio berdasarkan Subsektor Industri Lembaga Keuangan

\begin{tabular}{lcccccc}
\hline \multicolumn{1}{c}{ Sub Sektor } & N & RET & CR & EPS & DER & ROA \\
\hline Perbankan & 44 & 44,24 & 46,5 & 48,53 & 66,73 & 37,38 \\
Lembaga Pembiayaan & 15 & 47,13 & 46,5 & 47,67 & 40,43 & 52,73 \\
Sekuritas/Perusahaan Efek & 11 & 53,32 & 46,5 & 34,91 & 17,14 & 53,45 \\
Asuransi & 14 & 40,86 & 46,5 & 57,50 & 32,36 & 64,18 \\
Lainnya & 9 & 62,11 & 51,67 & 36,83 & 20,78 & 49,89 \\
\hline
\end{tabular}

Tabel 4: Hasil Uji Beda Berdasarkan Subsektor

\begin{tabular}{|l|r|r|r|r|r|}
\hline Keterangan & \multicolumn{1}{|c|}{ RET } & \multicolumn{1}{c|}{ CR } & \multicolumn{1}{c|}{ EPS } & \multicolumn{1}{c|}{ DER } & \multicolumn{1}{c|}{ ROA } \\
\hline Chi-Square & 4,610 & 9,333 & 5,754 & 50,477 & 12,676 \\
Asymp. Sig. & 0,330 & 0,053 & 0,218 & 0,000 & 0,013 \\
\hline
\end{tabular}


Menganalisis lebih lanjut terkait
peringkat kinerja perusahaan yang melakukan tax amnesty, analisis dilakukan dengan menguji kinerja berdasarkan subsektor karena terdapat temuan menarik sebelumnya. Subsektor dengan kemampuan menghasilkan laba yang tinggi justru tidak diminati investor. Subsektor dengan risiko tinggi (perbankan) lebih diminati di pasar saham dibanding emiten subsektor yang memiliki risiko rendah. Hasil pengujian menunjukkan bahwa secara konsisten risiko perusahaan (DER), tingkat pengembalian aset (RoA), dan rasio lancar memiliki perbedaan antar subsektor yang diteliti. Hal menarik lainnya adalah perbedaan rasio lancar lebih disebabkan perbedaan dari 4 anggota subsektor (perbankan, lembaga keuangan, sekuritas, dan asuransi) dengan subsektor lainnya. Sub sektor lainnya adalah subsektor lembaga keuangan namun tidak bergerak di bdang asuransi, seuritas (efek), bank, dan lembaga pembiayaan. Salah satu contohnya adalah MNC Kapital Indonesia, perusahaan yang bergerak di bidang manajemen aset.

Berdasarkan temuan hasil pengujian dari 93 data yang diuji, tampak bahwa 53,8\% perusahaan yang masuk pada sektor lembaga keuangan belum berpartisipasi dalam program tax amnesty. Hal ini merupakan peluang bagi Dirjen pajak untuk membuat kebijakan untuk melakukan kembali program tax amnesty pada program kerja di kementerian Keuangan. Mungkinkah dapat dilakukan kembali tax amnesty? Temuan ini dapat menjadi salah satu dasar untuk menyusun kebijakan tersebut. Adapun tingkat pengembalian saham dan laba per saham tidak secara signifikan menunjukkan perbedaan. Temuan penting lainnya adalah perusahaan kelompok subsektor asuransi yang memiliki return terendah justru memiliki tingkat laba tertinggi. Dengan kata lain subsektor ini kurang diminati. Ahmar (201).

Penerapan pengampunan pajak (tax amnesty) di Indonesia berdasarkan UndangUndang Nomor 11 Tahun 2016 akan berjalan melalui beberapa periode hingga, namun dalam pelaksanaannya diperkirakan belum dapat berjalan secara maksimal karena adanya hambatan dari berbagai sisi yang dialami selama pelaksanaannya. Dalam pelaksanaan tax amnesty, Direktorat Jenderal Pajak menjalin kerjasama dengan pihakpihak terkait seperti Kepolisian, Komisi Pemberantasan Korupsi (KPK), Ikatan Konsultan Pajak Indonesia (IKPI), dan lembaga lain. Program ini telah diundangkan dalam Undang-Undang Republik Indonesia Nomor 11 Tahun 2016 tentang Pengampunan Pajak pada 1 Juli 2016. Pengampunan pajak ini untuk mempercepat pertumbuhan dan restrukturisasi ekonomi melalui pengalihan harga, yang antara lain akan berdampak terhadap peningkatan liquiditas domestik, perbaikan nilai tukar rupiah, penurunan suku bunga, dan peningkatan investasi. Oleh karena itu wajib pajak tidak perlu ragu-ragu untuk ikut serta dalam program pengampunan pajak karena undang-undang memberikan payung hukum yang jelas. Permasalahan mengenai penerapan pengampunan pajak (tax amnesty) di Indonesia berdasarkan Undang-Undang Nomor 11 Tahun 2016 beserta upaya penyelesaiannya, yaitu:Tax amnesty dianggap mencederai keadilan bagi masyarakat yang selama ini patuh membayar pajak. Apalagi pada tahun 1964 dan 1984, tax amnesty berjalan tidak efektif karena minimnya ketersediaan data perpajakan. Tidak ada lengkapnya basis data perpajakan membuka kemungkinan petugas pajak untuk mendeteksi kekayaan yang tak dilaporkan. Pengemplang pajak pun tak perlu khawatir akan tertangkap. Terlebih, kekayaan yang tidak dilaporkan pada umumnya berada di luar negeri sehingga benar-benar jauh dari jangkauan petugas pajak. Banyak yang menilai jika kekurangan penerimaan pajak tidak hanya bisa diselesaikan dengan kebijakan pengampunan pajak tersebut. Belum adanya kejelasan mengenai kewajiban bagi wajib pajak untuk menempatkan kekayaannya di dalam negeri, besar kemungkinan individu-individu yang meminta pengampunan pajak akan menyembunyikan kembali kekayaan mereka di luar negeri ketika manfaat tax amnesty tak lagi diberikan. Tax amnesty dalam rancangan 
anggaran pendapatan dan belanja negara (RAPBN) 2016 dianggap sebagian orang bukan untuk kepentingan masyarakat. Mereka menilai, tax amnesty hanya untuk kepentingan pengusaha yang memiliki dana besar di luar negeri. Adapun upaya penyelesaian yang dilakukan : Penggunaan dana pajak direalisasikan bagi kepentingan masyarakat luas dan pembangunan negara sehingga hasil yang didapat dari tax amnesty dapat dirasakan secara adil oleh seluruh lapisan masyarakat. Pelaksanaan tax amnesty dengan sistem yang lebih akurat dengan pelaporan kekayaan pajak bagi wajib pajak dengan kekayaan mereka baik yang ada di dalam negeri ataupun di luar negeri sehingga dapat dicapai hasil yang maksimal.

Seluruh wajib pajak dikenakan pajak sesuai dengan kewajiban masing-masing tanpa mementingkan salah satu kalangan, sehingga tidak adanya anggapan bahwa hanya mementingkan salah satu kalangan. Pelaksanaan tax amnesty yang diperpanjang selama beberapa periode dan sosialisasi secara menyeluruh kepada wajib pajak untuk membayar pajak agar meningkatkan kesadaran wajib pajak bahwa pembayaran pajak digunakan untuk kepentingan bersama.

\section{Kesimpulan, Keterbatasan dan Implikasi Hasil Penelitian}

Penelitian bertujuan menginvestigasi kepatuhan wajib pajak badan dalam hal program tax amnesty dan menganalisis kinerja keuangan perusahaan yang berpatisipasi dan belum atau tidak berpartisipasi dalam program tax amnesty yang dicanangkan oleh Direktorat Jenderal Perpajakan. Keikutsertaan tax amnesty didasarkan pada pengungkapan terkait PSAK 70 tentang pengampunan pajak. Jika pada catatan atas laporan keuangan terdapat pengungkapan dan penejlasan tentang PSAK 70 maka perusahaan tersebut berpartisipasi dalam program tax amnesty. Berdasarkan hasil pengujian terbukti perusahaan yang belum berpartisipasi lebih banyak dibanding yang berpartisipasi. Dengan kata lain jika partisipasi program taxamnesty diasumsikan sebagai bagian dari kepatuhanpajak, maka kepatuhan untuk berpartisipasi dalam program tax amnesty masih belum optimum.
Secara konsisten kinerja keuangan dalam bentuk profitabilitas, risiko perusahaan, rasio lancar menunjukkan perbedaan antar subsektor. Risiko perusahaan sampel yang berpartisipasi dan tidak berpartisipasi dalam program tax amnesty terbukti berbeda.

\section{Daftar Referensi}

Adam, O., Tuli, H., \& Husain, S. P. (2017). Pengaruh Program Pengampunan Pajak Terhadap Efektivitas Penerimaan Pajak di Indonesia. Akuntabilitas, 10(1), 31-40.

Ahmar, N. (2018, September). Role of public accountants to the success of tax amnesty in financial institutions and banking in indonesia. In proceedingS (Vol. 1, No. $1)$.

Arief, M., \& KH, I. I. (2019). Penerapan Tax amnesty terhadap Pelayanan Pajak, Penerimaan Pajak dan Pengetahuan Pajak melalui Kepatuhan Wajib Pajak di KPP Kanwil DJP Sumatera Utara I. Jurnal Ilman: Jurnal Ilmu Manajemen, 6(2).

Azyus, D. I., Syahbandir, M., \& Rahayu, S. W. (2017). Implementasi Kebijakan Pengampunan Pajak Kaitannya Dengan Kepatuhan Wajib Pajak di Aceh. Syiah Kuala Law Journal, 1(1), 17-39.

Bawazier, F. (2018). Reformasi Pajak di Indonesia Tax Reform In Indonesia. Jurnal Legislasi Indonesia, 8(1), 1-28.

Damayanti, L. D., \& Amah, N. (2018). Kepatuhan Wajib Pajak Orang Pribadi: Pengaruh Modernisasi Sistem Administrasi dan Pengampunan Pajak. Assets: Jurnal Akuntansi dan Pendidikan, 7(1), 57-71.

Dewi, S. K., \& Merkusiwati, N. K. L. A. (2018). Pengaruh Kesadaran Wajib Pajak, Sanksi Perpajakan, E-Filing, dan Tax amnesty Terhadap Kepatuhan Pelaporan Wajib Pajak. E-Jurnal Akuntansi, 1626-1655. 
Dewi, S. K., \& Merkusiwati, N. K. L. A. (2018). Pengaruh Kesadaran Wajib Pajak, Sanksi Perpajakan, E-Filing, dan Tax amnesty Terhadap Kepatuhan Pelaporan Wajib Pajak. E-Jurnal Akuntansi, 1626-1655.

Dura, J., \& Murniati, A. (2019). Likuiditas Dan Resiko Kredit Bank Persepsi Pasca Kebijakan Tax Amnesti. Jurnal Ilmiah Bisnis dan Ekonomi Asia, 13(1), 1-6.

Istighfarin, N., \& Fidiana, F. (2018). Tax amnesty dari perspektif masyarakat pajak. AKRUAL: Jurnal Akuntansi, 9(2), 142-156.

Jamil, N. A. (2017). Efektivitas Penerapan Tax amnesty di Indonesia. Academica: Journal of Multidisciplinary Studies, 1(1), 51-65.

Kartika, C. A., Nangoi, G. B., \& Lambey, R. (2017). Analisis Efektivitas Penerapan Tax amnesty (Pengampunan Pajak) Terhadap Penerimaan Pajak Dari Wajib Pajak Badan Usaha Pada Kantor Pelayanan Pajak Pratama Manado. Jurnal EMBA: Jurnal Riset Ekonomi, Manajemen, Bisnis dan Akuntansi, 5(2).

Kurniawan, B. R., Juanda, B., \& Bakhtiar, T. (2019). Kajian Kebijakan Pengampunan Pajak dengan Pendekatan Eksperimental. Jurnal Ekonomi Dan Pembangunan Indonesia, 19(1), 21-48.

Kusuma, A. I. (2016). Pengampunan pajak (tax amnesty) sebagai upaya optimalisasi fungsi pajak. INOVASI, 12(2), 270-280.

Mareti, E. D., \& Dwimulyani, S. (2019, April). Pengaruh Pemahaman Peraturan Perpajakan, Kualitas Pelayanan Fiskus, Sanksi Pajak Dan Tax amnesty Terhadap Kepatuhan Wajib Pajak Dengan Preferensi Resiko Sebagai Variabel Moderasi. In Prosiding Seminar Nasional Pakar (pp. 2-51).
Murniati, A., \& Dura, J. (2019). Analisis Kinerja Keuangan Bank Persepsi Sebelum Dan Setelah Implementasi Kebijakan Tax amnesty. Jurnal Penelitian Teori \& Terapan Akuntansi (PETA), 4(1), 33-50.

Pravasanti, Y. A. (2018). Dampak Kebijakan dan Keberhasilan Tax amnesty bagi Perekonomian Indonesia. Kompartemen: Jurnal Ilmiah Akuntansi, 16(1).

Rahayu, N. (2017). Pengaruh pengetahuan perpajakan, ketegasan sanksi pajak, dan Tax amnesty terhadap kepatuhan wajib pajak. Akuntansi Dewantara, 1(1), 15-30.

Rorong, E. N., Kalangi, L., \& Runtu, T. (2017). Pengaruh Kebijakan Tax amnesty, Kesadaran Wajib Pajak dan Sanksi Pajak Terhadap Kepatuhan Wajib Pajak Orang Pribadi di KPP Pratama Manado. Jurnal Riset Akuntansi Going Concern, 12(2).

Sari, D. P., \& Latupeirissa, J. (2019). Analisis Perbedaan Penerimaan Pajak Sebelum Dan Sesudah Penerapan Program Pengampunan Pajak (Tax amnesty) Pada Kpp Pratama Denpasar. JSAM (Jurnal Sains, Akuntansi dan Manajemen), 1(1), 1-34.

Sari, D. P., \& Latupeirissa, J. (2019). Analisis Perbedaan Penerimaan Pajak Sebelum Dan Sesudah Penerapan Program Pengampunan Pajak (Tax amnesty) Pada Kpp Pratama Denpasar. JSAM (Jurnal Sains, Akuntansi dan Manajemen), 1(1), 1-34.

Setiawan, P. A., SinarwatI, N. K., Yuniarta, G. A., \& AK, S. (2017). Kebijakan Pengampunan Pajak (Tax amnesty) Berdasarkan Undang-Undang Nomor 11 Tahun 2016 (Studi Kasus Pada Kantor Pelayanan Pajak (KPP) Pratama Singaraja). JIMAT (Jurnal Ilmiah Mahasiswa Akuntansi) Undiksha, 7(1).

Setyaningsih, T., \& Okfitasari, A. (2018). Mengapa Wajib Pajak Mengikuti Tax 
amnesty (Studi Kasus di Solo). EKUITAS (Jurnal Ekonomi dan Keuangan), 20(4), 415-433.

Setyawati, E. (2019). Tinjauan Hukum Kewajiban Verifikasi Dan Validasi Bea Perolehan Tanah Dan Bangunan (Bphtb) Bagi Wajib Pajak Yang Mengikuti Pengampunan Pajak Di Kota Semarang. Spektrum Hukum, 14(2), 265278.

Surbakti, J., Ahmar, N., \& Darmansyah, S. (2019). Dampak Implementasi Standar Akuntansi Pengampunan Pajak (Tax amnesty) Terhadap Kinerja Keuangan Dan Return Saham. Jimea-Jurnal Inovasi Manajemen Ekonomi Dan Akuntansi, 1(2).

Suryadi, A. (2017). Reaksi Pasar Modal Terhadap Pengesahan Uu Engampunan Pajak (Tax amnesty). Jurnal Manajemen Update, 6(2).

Suyanto, S., \& Putri, I. S. (2017). Pengaruh Persepsi Wajib Pajak Tentang Kebijakan Tax amnesty (Pengampunan Pajak), Dan Motivasi Membayar Pajak Terhadap Kepatuhan Perpajakan. Jurnal Akuntansi, 5(1), 49-56.
Suyanto, S., \& Putri, I. S. (2017). Pengaruh Persepsi Wajib Pajak Tentang Kebijakan Tax amnesty (Pengampunan Pajak), Dan Motivasi Membayar Pajak Terhadap Kepatuhan Perpajakan. Jurnal Akuntansi, 5(1), 49-56.

Trisnasari, A. T. S., Edy Sujana, S. E., Herawati, N. T., \& AK, S. (2017). Pengaruh Kesadaran Wajib Pajak, Sosialisasi Perpajakan dan Pengetahuan Perpajakan Terhadap Kemauan Wajib Pajak Dalam Mengikuti Program Tax amnesty (Studi Kasus Pada Wajib Pajak Orang Pribadi Pada KPP Pratama Singaraja). JIMAT (Jurnal Ilmiah Mahasiswa Akuntansi) Undiksha, 7(1).

Wijaya, A. H. (2019). Nominee Dalam Saham Terkait Kebijakan Pengampunan Pajak. Notaire, 1(2), 197-212.

Yasa, I. N. P., Sujana, E., \& Andriawan, I. G. D. (2019). Persepsi Wajib Pajak Atas Program Tax amnesty Dalam Perspektif Budaya Meboya. Jurnal Ilmiah Akuntansi, 4(1). 
JRAP (Jurnal Riset Akuntansi dan Perpajakan) Vol. 6, No. 2, Desember 2019, hal 127-139 ISSN 2339-1545 